Ann. Génét. Sél. anim., I977, 9 (3), 387-39r.

\title{
Estimation of general and specific combining abilities from a diallel cross of three inbred lines of Fayoumi chicks
}

\author{
M. SOLTAN, F. H. ABDOU, M. ABD-ELLATIF and H. AYOUB * \\ Faculty of Agric., Shebin El-Kom, Tanta University, Egypt.
}

\section{Summary}

Three inbred lines of Fayoumi chicks were incrossed in diallel mating system to estimate general and specific combining ability. The inbreeding coefficients in three inbred lines were $25,37.5$ and 50 per cent.

L 25 showed the highest g.c.a. in fertility and body weight at 8 weeks of age. L 37,5 exhibited the best g.c.a. in viability, while $\mathrm{L} 50$ gave the best g.c.a. in hatchability.

The inbreeding coefficient of sire had a highly significant effect on both fertility and hatchability while its effect on viability and body weight at 8 weeks of age was not significant.

L $25 \times \mathrm{L} 37,5$ incrossbred chicks gave the best s.c.a. in viability and body weight, fertility and hatchability.

\section{Introduction}

The model of inbreeding and incrossing has been applied successfully in chicken production and has played a major role in many broiler and egg production investigation programs.

YAO (I96r) using diallel crosses of inbred lines of chickens reported that line effect was highly significant for Io - week body weight. CoLE and HuTr (I962) found that hybrids resulted from crossing 2 strains of white Leghorns showed a high degree of heterosis in egg production, hatchability and body weight. EISEN et al. (1964) reported that cross effects were highly significant for 8 week body weight and adult mortality.

Hazel and Lamoreux (I947), and Goto and NORDS KOG (I959), using Leghorn breed of Chicken suggested that nicking was not of major importance. HALE

* Faculty of Agric., Ain Shams Univ. 
and Clayton (1965) found the same concept in Leghorn breed and crosses, showing that genetic interactions were unimportant. HILL and NoRDs KOG (I958) stressed the importance of general combing ability over specific combining ability.

WEARDEN et al. (I964) in a full-diallel crossing experiment using 3 white Leghorn and 3 Rhode Island Red " closed flock" strains suggested that general combining ability was much more important than specific combining ability for five and ten-month body weights. Contrarily, specific combining ability was estimated to be of more importance for sexual maturity, hen day and hen-housed egg production to 260 and 470 days. However ERAsmus et al. (rg68), illustrated the importance of specific combining ability as compared with the general combining ability.

\section{Material and methods}

The main objective of the present study was to estimate general and specific combining ability (g.c.a. and s.c.a.) of Fayoumi chicks resulting from incrossing of three inbred lines.

Full -and half-sib matings were used through 4 years (i.e. I97I-I974) to get different inbreeding intensities. Inbreeding coefficients were 25, 37.5 and 50 per cent in three different inbred lines. All possible combinations along with the three inbred lines were represented using diallelic mating system. The traits studied were fertility, hatchability, viability and body weight. The birds used in this study are the same as described in the paper by SolTAN et al. (in press).

General and specific combining ability were calculated as means (FALCoNER, r964, p. 284) and also tested by the analysis of variance (GALAL et al., I972). $\left(^{*}\right)$ Maternal influence for each inbred line was estimated as the average of differences between the reciprocal incrosses which include that inbred line. Heterosis percentages were also estimated as the deviation of the incross mean from the average of the two parental inbreds. All the percentages data were converted to angles with the arcsin transformation using tables given by SNEDECOR, I959.

\section{Results and discussion}

Data presented in Table $\mathrm{I}$ show the average of general and specific combining ability on some traits of Fayoumi incrossbreds. It was noticed that $\mathrm{L} 25$ showed the highest general combining ability in both fertility and body weight at 8 weeks of age, while it was moderate in hatchability and viability percentage at the same age. L 37.5 gave the highest general combining ability in viability, while $\mathrm{L} 50$ showed the best general combining ability in hatchability. The interaction between sires and dams, present in all the traits except body weight (see table 2) could be due to nicking between the genes of the sires and dams. Incrossbred chicks produced from L $25 \times \mathrm{L} 37,5$ mating showed the best effect on viability and body weight. These improvements in viability and body weight may be due

$\left.{ }^{*}\right)$ General combining ability is defined as the average performance of a breed, strain or line in a cross combination, while specific combined ability (" nicking") is defined as the deviation in performance of a cross from the expectation on the basis of the average performance of the parental breeds, strains or lines involved. 
TABLE I

Average General and specific combining ability in some traits in 1975 Aptitude générale et spécifique à la combinaison pour certains caractères en 1975

\begin{tabular}{|c|c|c|c|c|c|c|}
\hline \multirow{2}{*}{\multicolumn{3}{|c|}{ Combining ability }} & \multicolumn{4}{|c|}{ Traits } \\
\hline & & & $\begin{array}{l}\text { Fertility } \\
\quad \pm \text { S.E }\end{array}$ & $\begin{array}{c}\text { Hatchability } \\
\pm \text { S.E }\end{array}$ & $\begin{array}{c}\text { Viability at } \\
8 \text { weeks } \pm \text { S.E }\end{array}$ & $\begin{array}{l}\text { Body weight at } \\
8 \text { weeks } \pm \text { S.E }\end{array}$ \\
\hline $\begin{array}{l}\text { G.C.A. for: } \\
\begin{array}{lll}\text { L } 25 & \cdot \\
\text { L } 37.5 & . & . \\
\text { L } 50.0 & \cdot\end{array}\end{array}$ & $\begin{array}{ll}\cdot & \cdot \\
\cdot & \cdot \\
\cdot & \cdot\end{array}$ & $\begin{array}{ll}\cdot & \cdot \\
\cdot & \cdot \\
\cdot & \cdot\end{array}$ & $\begin{array}{l}77.4 \pm 4.9 \\
72.7 \pm 4.1 \\
73.8 \pm 4.4\end{array}$ & $\begin{array}{l}57.5 \pm 3.2 \\
57.2 \pm 2.9 \\
57.9 \pm 3.6\end{array}$ & $\begin{array}{l}64.7 \pm 5.5 \\
67.7 \pm 5.1 \\
63.5 \pm 3.1\end{array}$ & $\begin{array}{l}280.4 \pm 31.5 \\
275.6 \pm 33.2 \\
270.2 \pm 31.0\end{array}$ \\
\hline $\begin{array}{l}\text { S.C.A. for: } \\
25 \text { and } 37.5 \\
25 \text { and } 50 . \\
37.5 \text { and } 50\end{array}$ & $\begin{array}{l}. \\
\cdot . \\
\cdot \\
.\end{array}$ & $\begin{array}{l}. \\
. \\
.\end{array}$ & $\begin{array}{l}+1 . x \pm .9 \\
+2.9 \pm .9 \\
-4.1 \pm 1.1\end{array}$ & $\begin{array}{l}-0.5 \pm .8 \\
+0.5 \pm .8 \\
-0.05 \pm .7\end{array}$ & $\begin{array}{l}+2.7 \pm .6 \\
3.6 \pm \mathrm{I} . \mathrm{I} \\
+0.9 \pm \mathrm{I} .2\end{array}$ & $\begin{array}{l}+7.8 \pm 7.2 \\
-0.2 \pm 6.6 \\
-7.5 \pm 7.1\end{array}$ \\
\hline
\end{tabular}

G.C.A. = General combining ability.

S.C.A. = Specific combining ability.

to better general combining ability in $\mathrm{L} 25$ and L 37.5 and also to a favourable specific combining ability between them. However, this incrossbred was moderate in fertility.

Table 2 shows the effect of sire and dam on different traits. It was noticed that the coefficient of inbreeding of sire hadhighly significant effect on both fertility and hatchability, while its effect on viability and body weight at 8 weeks of age was not significant. It was also noticed that the dam's inbred effect was highly significant on hatchability, while non-significant for all the other traits.

Table 3 shows maternal influence of different inbred lines on traits studied. It was noticed that $\mathrm{L} 25$ exhibited the best maternal ability in fertility, viability and body weight, while $\mathrm{L} 50$ gave the highest maternal ability in hatchability. The same trend, except viability, was observed in g.c.a. (Table I). Therefore, it seems resonable to take both g.c.a. and maternal ability into consideration when evaluating an inbred line performance in incrosses.

Heterosis percentages for different incrosses are given in Table 4. It was observed that $\mathrm{L} 25 \times \mathrm{L} 50$ incross gave the highest heterosis in fertility and hatchability, while $\mathrm{L} 25 \times \mathrm{L} 37.5$ gave the best heterosis in viability and body weight. It was also clear that both s.c.a. and heterosis percentages gave almost the same trend and it is quite resonable to consider any one of them in explaining differences among incrosses.

These results indicate the possibility of improving the native breed; Fayoumi chickens, by incrossing inbred lines and detecting the most favourable incrossbreds which give the best combinability. 
TABLE 2

Variance analysis of genetic factors for traits studied Analyse de variance concernant des facteurs génétiques pour les caractères étudiés

\begin{tabular}{|c|c|c|c|c|c|}
\hline Source of variation & d.f & Fertility & Hatchability & $\begin{array}{l}\text { Viability } \\
\text { at } 8 \text { weeks } \\
\text { of age }\end{array}$ & $\begin{array}{c}\text { Body } \\
\text { weight at } \\
8 \text { weeks } \\
\text { of age }\end{array}$ \\
\hline 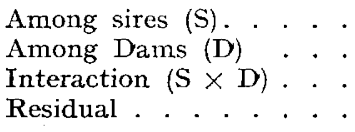 & $\begin{array}{l}2 \\
2 \\
4\end{array}$ & $\begin{array}{r}\text { I } 647.8\left(^{* *}\right) \\
64.8 \\
3399.9(* *) \\
\text { I } 23.1\end{array}$ & $\begin{array}{r}477.1\left(^{* *}\right) \\
\text { I } 55.3(* *) \\
343.4(* *) \\
7 \text { I.3 }\end{array}$ & $\begin{aligned} 419.9 \\
57.9 \\
378.8 \quad(*) \\
125.9\end{aligned}$ & $\begin{array}{r}245 \cdot 7 \\
8.4 \\
187 \cdot 7 \\
\mathrm{I} 28.2\end{array}$ \\
\hline $\begin{array}{l}\text { Degrees of freedom for re- } \\
\text { sidual . } . . . \\
\end{array}$ & & I 8 & I 8 & I 8 & 324 \\
\hline
\end{tabular}

(*) Significant at 5 p. roo level.

(**) Significant at I p. Ioo level.

TABLE 3

Estimated maternal infuence of different inbred lines on traits studied

Estimation de l'influence maternelle de différentes lignées consanguines sur les caractères étudiés

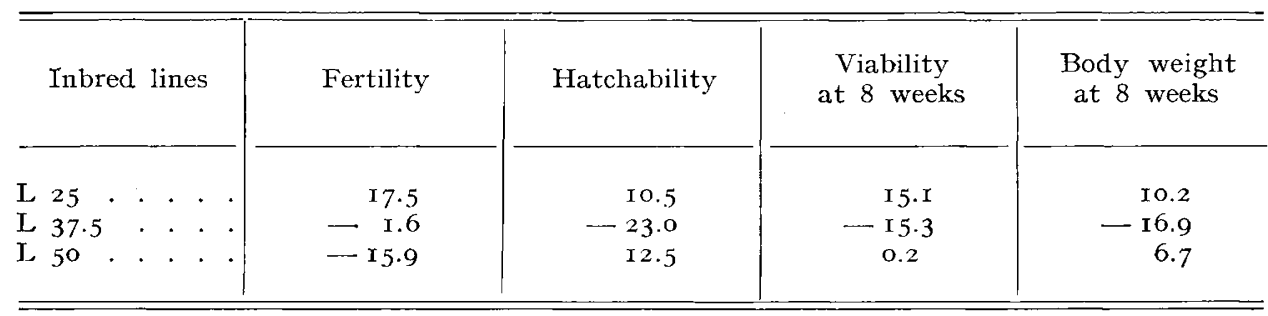

TABLE 4

Heterosis percentage for different incrosses

Pourcentage d'hétérosis pour les différents croisements

\begin{tabular}{|c|c|c|c|c|}
\hline Incrosses & Fertility & Hatchability & $\begin{array}{l}\text { Viability } \\
\text { at } 8 \text { weeks }\end{array}$ & $\begin{array}{l}\text { Body weight } \\
\text { at } 8 \text { weeks }\end{array}$ \\
\hline $\begin{array}{l}\mathrm{L} 25 \times \mathrm{L} 37.5 . \\
\mathrm{L} 25 \times \mathrm{L} 55^{\circ} . \\
\mathrm{L} 37.5 \times \mathrm{L} 50^{\circ} .\end{array}$ & $\begin{array}{l}5.27 \\
3.6 \mathrm{I} \\
0.00\end{array}$ & $\begin{array}{c}8.56 \\
27.0 \\
-5.61\end{array}$ & $\begin{array}{r}7.03 \\
-\mathbf{I} 2.13 \\
3.24\end{array}$ & $\begin{array}{r}7.84 \\
-2.29 \\
-2.10\end{array}$ \\
\hline
\end{tabular}




\title{
Résumé
}

\author{
Estimation de l'aptitude générale et spécifique à la combinaison \\ à partir d'un croisement diallèle de trois lignées consanguines de poulets Fayoumi
}

Trois lignées consanguines de Fayoumi ont été croisées dans un système diallèle pour estimer l'aptitude générale et spécifique à la combinaison. Les coefficients de consanguinité dans ces trois lignées étaient $25,37,5$ et 50 p. roo.

L 25 montrait la g.c.a. la plus élevée pour la fertilité et le poids corporel à 8 semaines d'âge, L 37,5 pour la viabilité et L 50 pour le taux d'éclosion.

Le coefficient de consanguinité du père avait un effet hautement significatif à la fois sur la fertilité et l'éclosion, alors que son effet sur la viabilité et le poids à 8 semaines d'âge n'était pas significatif.

Les poussins croisés L $25 \times$ L 37,5 donnaient la meilleure S.C.A. pour la viabilité, le poids corporel, la fertilité et l'éclosion.

\section{References}

Cole R. K. and Hutt F. B., 1962. The effect of continued selection in pure strains upon their combinability. Poult. Sci., 41, I636.

Eisen E. J., Bohren B. B., McKean H. E., King S. C., I964. Genetic combining ability of light and heavy inbred lines in single crosses. Poult. Sci., 43, I3 5.

Erasmus J. E., Stevens J. M., JordaAn J. P., Strydom G. S., I968. The combining ability of inbred lines of the Australorp and Leghorn breeds of fowl.. Proc. $3^{r d}$ Congr. S. Afr. Genet. Soc. Pretoria, 1966, 94-98 (in Anim. breed abstr. 37,4 I 77 ).

FALConer D. S., 1964. Introduction to quantitative genetics. Olivier § Boyd, Edinburgh, London.

Galal E.S.E., Aboul-Naga A., Extawil E. A., Khishin E. S., i972. Estimates of combining abilities and maternal influence in crosses between Merino, Ossimi and Barki sheep. Anim. Prod., 15, 47-52.

Goto E., Nordskog A. W., I959. Heterosis in poultry. Estimation of combining ability variance from diallel crosses of inbred lines in the fowl. Poult. Sci., 38, I38I-I388.

Hale R. W., Clayton G. A., I965. A diallel crossing experiment with two breeds of laying fowl. Brit. Poult. Sci., 6, I53-r 74 .

Hazel L. N., Lamoreux W. F., I947. Heritability, maternal effects and nicking in relation to sexual maturity and body weight in white Leghorns. Poult. Sci., 24, 508-5I4.

Hill J. F., Nordskog A. W., r958. Heterosis in poultry. III. Predicting combining ability performance in the crossbred fowl. Poult. Sci., 37, I r6o-I 69.

Soltan M., Abdou F. H., ABD-Ellatrf M., Ayoub H. Heterosis in Fayoumi strain incrossing. Ann. Génét. Sél. anim. (in press).

Snedecor G. W., I959. Statistical methods. Iowa State college Press, Ames, Iowa.

Wearden S., Tindell D., Craig J. V., I964. Use of a full diallel cross to estimate general and specific combining ability in chickens. Poult. Sci., 44, I043-1053.

YAO T. S., I96I. Genetic variations in the progenies of the diallel crosses of inbred lines of chickens. Poult. Sci., 40, ro48-1059. 